\title{
Comparative Analysis between the Integrating Company model and the Export Consortium in Mexico
}

\section{Análisis Comparativo entre el modelo de Empresa Integradora y Consorcio de Exportación en México}

\author{
ARREDONDO-HIDALGO, María Guadalupe †, CONRAUD-KOELLNER, Eva, ALCOCER-LUQUE \\ María Clementina and MORENO-ÁVILA, Fátima de la Purísima
}

Universidad de Guanajuato. Fraccionamiento El Establo

ID $1^{\text {st }}$ Author: María Guadalupe, Arredondo-Hidalgo / ORC ID: 0000-0002-4971-4069

ID $1{ }^{\text {st }}$ Coauthor: Eva, Conraud-Koellner / ORC ID: 0000-0002-9121-1641

ID $2^{\text {nd }}$ Coauthor: María Clementina, Alcocer-Luque / ORC ID: 0000-0002-1212-6132

ID $3^{\text {rd }}$ Coauthor: Fátima de la Purísima, Moreno-Ávila / ORC ID: 0000-0003-3037-1606

DOI: 10.35429/JPE.2019.4.3.10.20

Received March 10, 2019; Accepted June 18, 2019

\begin{abstract}
Globalization has forced entrepreneurs of all types of companies to orient their steps of commercial leadership, to search for new forms of internationalization in order to be at the forefront of business transcendence. In Mexico, about $98 \%$ are small and medium-sized companies who seek to consolidate their exportable offer through different forms of international commercial collaboration. These figures involve substantive benefits such as: fair trade, specialization and the consolidation of the exportable supply. This research will address the figures of Integrative Company and the Export Consortium to make a comparison between both forms of international business cooperation. This qualitative research with a grounded theory research design had an extensive review of the literature that was carried out. It is concluded that although both figures have similar characteristics, the Integrating Company model offers more fiscal support to microenterprises, while the Export Consortium focuses on the work of small and medium enterprises.
\end{abstract}

Integrative Company, Export Consortium, Fair trade

\begin{abstract}
Resumen
La globalización ha obligado a los empresarios, de todo tipo de empresas, a orientar sus pasos de liderazgo comercial, para buscar nuevas formas de internacionalización, a fin de estar a la vanguardia en materia de trascendencia empresarial. En México, alrededor del $98 \%$ de las empresas son pequeñas y medianas, quienes buscan consolidar su oferta exportable a través de diferentes formas de colaboración comercial internacional. Estas figuras involucran beneficios sustantivos tales como: comercio justo, especialización y la consolidación de la oferta exportable. La presente investigación, abordará las figuras de: Empresa Integradora y la de Consorcio de Exportación para realizar una comparativa entre ambas formas de cooperación de negocios internacionales. Se trata de una investigación cualitativa con diseño de la investigación de teoría fundamentada, en la que se llevó a cabo una extensa revisión de la literatura. Se concluye que a pesar de que ambas figuras poseen características similares, el modelo de Empresa Integradora ofrece más apoyo fiscal a las microempresas, mientras que el Consorcio de Exportación se centra en el trabajo de las pequeñas y medianas empresas.
\end{abstract}

Empresa Integradora, Consorcio de Exportación, Comercio justo

Citation: ARREDONDO-HIDALGO, María Guadalupe, CONRAUD-KOELLNER, Eva, ALCOCER-LUQUE María Clementina and MORENO-ÁVILA, Fátima de la Purísima. Comparative Analysis between the Integrating Company model and the Export Consortium in Mexico. Journal-Public Economy. 2019. 3-4: 10-20

\footnotetext{
$\uparrow$ Researcher contributing as first author
} 


\section{Introduction}

The commercial opening of Mexico dates from its accession to the GATT (General Agreement for Tariffs and Trade), in the year 1986, and particularly later in 1994, with the signing of the North American Free Trade Agreement (NAFTA). From this period, commercial promotion models emerge, which the Mexican government incorporated as policies, in order to encourage the growth of micro, small and medium enterprises, evaluating and promoting the competitive advantages of the country's products. For the rest of the world, particularly in Europe, the antecedents of the figures related to business association for export, are born under the scheme, both of integrating companies, and of export consortia shortly after the Second World War where economic instability, It was the common denominator for companies that were born that moment of world crisis.

This research is divided into two sections: the first one addresses the concept of an integrating exporting company; The second section explains the export consortium model. The qualitative approach of this research is based on the objective of performing a descriptive analysis of the characteristics of each figure. For this purpose, a thorough review of the literature was made from various sources where information was found that supports everything that an integrating export company and an export consortium must have in order to comply with said model.

\section{Integrating Company}

According to the Decree that promotes the organization of integrating companies, published in the Official Gazette of the Federation (1993), the integrating company is defined as a business organization that associates natural or legal persons of micro, small and medium scale in branches and regions With export potential. Its corporate purpose is to provide specialized services to its partners, such as: managing financing, buying materials and supplies together, and selling production in a consolidated manner. To understand the importance of this figure in our country, the evolution of this concept in the world will be analyzed below.

\section{International historical background of Integrative Companies}

From the seventies, the context of the economy presents changes in the forms of business organization. An increase in cooperation between companies is observed nationally and internationally. Table 1 shows this chronology in countries such as Italy, Germany and Japan (Ministry of Economy, s.f.).

\begin{tabular}{|l|l|l|}
\hline \multicolumn{1}{|c|}{ Period $\begin{array}{l}\text { Country } \\
\text { period }\end{array}$} & $\begin{array}{l}\text { Its creation favored the ability to } \\
\text { adapt to the structural changes of a } \\
\text { new economic system that was } \\
\text { evolving. The companies grew and } \\
\text { gave the space to more units for } \\
\text { the consolidation of the model. }\end{array}$ \\
\hline The 80's & Germany & $\begin{array}{l}\text { Especially in some regions of the } \\
\text { country, the industry is articulated } \\
\text { as a network that links both large } \\
\text { and SMEs, who maintain total } \\
\text { autonomy with respect to large } \\
\text { companies, since they are related } \\
\text { to several contractors, which } \\
\text { differentiates them from the } \\
\text { traditional model of small } \\
\text { businesses dedicated to } \\
\text { outsourcing where they depend on } \\
\text { a single contractor. }\end{array}$ \\
\hline $\begin{array}{l}\text { Start of } \\
\text { the 60s }\end{array}$ & Korea & $\begin{array}{l}\text { The government created laws and } \\
\text { measures of technological } \\
\text { development, focused on SMEs to } \\
\text { form cooperatives and strengthen } \\
\text { their activity: improvement of } \\
\text { human resources, dissemination } \\
\text { and orientation, development of } \\
\text { basic technology and incentives } \\
\text { for technological development. }\end{array}$ \\
\hline $\begin{array}{l}\text { Government promotion of large } \\
\text { companies with business groups, } \\
\text { developing economies of scale to } \\
\text { develop these alliances. }\end{array}$ \\
\hline
\end{tabular}

Table 1 Chronology of the integrating companies in the world

Source: Own elaboration with data from the Ministry of Economy (s.f.).

\section{Historical background of the Integrating Company in Mexico}

Just as the integrating companies have taken place in different continents, in Mexico, they arise from a need to give competitiveness to rural businesses given the signing of NAFTA, in order to face the challenges ahead, since among the main problems was the low productivity, lack of organization, ignorance of economic integration (Marín, 2017). The economic environment itself, which was understood as globalized, produced in companies the need to become competitive. 
Thus, the then Secretary of Commerce and Industrial Development (SECOFI), gave rise to the Decree that promoted the organization of Integrating Companies, published in the Official Gazette of the Federation (1993). This scheme of integration of companies pursues the efficiency in the production process on the basis of small productive scales of horizontal integration, in order to obtain goods and services of quality and competitive price, which favors the concurrence to the export market. This legal system establishes that due to the growing competition, integrative companies must be given operational flexibility so that they can buy and sell on behalf of their associates, thereby achieving a better negotiating position in the market. Likewise, it indicates that it is essential to obtain the maximum yield of the productive capacity that agglutinates the society, so it is convenient to allow the integrating company to market a proportion of its goods and services among third parties.

\section{Objectives of the Integrating Company}

Like all strategic alliances, the Integrating Company has specific objectives that seek the growth of MSMEs. Based on data from the National Entrepreneur Institute (s.f.) below, the objectives of an integrating company are listed:

1. Raise your bargaining power in the supply, marketing, financial and technological markets, among others.

2. Consolidate its presence in the domestic market and increase its participation in the export market.

3. Promote the specialization of the associated companies in products and processes that have comparative advantages.

\section{Functions developed and services provided by the Integrating Company}

Reyes (2011) analyzes the functions and services that the decrees of creation and modification of integrating companies incorporate:

a.

Technological: Acquisition, adaptation,
assimilation and technological
innovation. Modernization of machinery
and equipment. Planning of the
productive process. Installation of
laboratories for research and
technological development.

b. Marketing: Search for national and export markets. Application of marketing and advertising techniques for the sale of their products, promotional catalogs and participation in fairs.

c. Design: Access to specialized services, development of better designs that meet the needs of the consumer, to achieve greater market penetration. Information services on fashion trends, both at home and abroad.

d. Subcontracting: Achieve the articulation and complementation of productive chains, coordinate smaller companies with larger ones, to avoid excessive vertical integrations. Develop outsourcing profiles required by other companies.

e. Financing: Manage on behalf of the partners, obtaining bank credits. Specialized advice to improve your financial position. Promotion and formation of co-investments of strategic alliances.

f. Common activities: Sell the production on behalf of the partners. Placement of consolidated offers. Consolidated purchases Acquire technology and technical assistance. Promote the renovation and innovation of machinery and equipment. Implement programs to improve quality and increase productivity.

g. Use of industrial waste: Advice to achieve greater use of recyclable materials, in order to contribute to the preservation of the environment. Promote the development of recycling technologies.

h. Administrative procedures: Advice on accounting, legal, tax and credit procedures for the operation of companies.

\section{Benefits granted by the Integrating Company}

According to the National Entrepreneur Institute (sf), the integrating company offers benefits to its participants: It increases competitiveness, economies of scale are created for its associates, access to specialized services is facilitated at low cost, avoids duplication of investments, promotes the specialization of the partners in certain processes and products. 
The essential thing is that it maintains the individuality of entrepreneurs in the internal decisions of their companies. Flexibility to adapt to any economic activity.

\section{Supports}

Based on data from the Ministry of Economy (s.f.), there are a number of supports designed for integrating companies:

Fiscal Support: you can benefit from the Simplified Taxation Regime for a period of 10 years with no income limit.

Financial Support: through the SME Fund, you can support in lines such as: training, studies, and productive projects. Export Support: when the partners have an export vocation, the integrating companies also have facilities to access programs for the promotion of exports such as:

a. Registry of Foreign Trade Companies (Ecex). Trading companies will be able to access international markets with administrative facilities and financial support from the Development Bank.

b. Highly Exporting Companies (Altex): Export promotion instrument, supports its operation through administrative and fiscal facilities.

c. Export Maquila Producers of merchandise destined for export are allowed to temporarily import the goods necessary to be used in the processing, processing and / or repair of export products.

\section{Training stages}

The incorporated process for the formation of an integrating company is identified in the following Table 2 .

\begin{tabular}{|c|c|}
\hline Stage & Description \\
\hline Sensitization & $\begin{array}{l}\text { Companies see the business } \\
\text { association as a key to achieving } \\
\text { competitiveness, to be part of } \\
\text { specialized services, to market in a } \\
\text { consolidated manner and thus adapt } \\
\text { and innovate assets and technology. }\end{array}$ \\
\hline $\begin{array}{l}\text { Preliminary } \\
\text { planning }\end{array}$ & $\begin{array}{l}\text { They identify the opportunity of a } \\
\text { business that is profitable. They know } \\
\text { the risks they have to face. They } \\
\text { define the ability to meet future } \\
\text { commitments. }\end{array}$ \\
\hline $\begin{array}{l}\text { Detailed } \\
\text { planning stage }\end{array}$ & $\begin{array}{l}\text { Start of work for a more complex and } \\
\text { deep planning. }\end{array}$ \\
\hline $\begin{array}{l}\text { Formation } \\
\text { and } \\
\text { constitution }\end{array}$ & $\begin{array}{l}\text { Request a free writing to the Ministry } \\
\text { of Economy to register the integrating } \\
\text { company in the National Registry, } \\
\text { attached a copy of the charter and the } \\
\text { feasibility project. } \\
\text { For its constitution it is required: } \\
\text { Minimum of } 4 \text { members and there is } \\
\text { no maximum number of members. } \\
\text { Have a minimum capital of } \$ 50,000 . \\
\text { The shareholding of each partner must } \\
\text { not exceed } 30 \% \text { of the share capital. } \\
\text { Present to the Ministry of Economy: } \\
\text { Draft constitutive act in accordance } \\
\text { with the General Law of Commercial } \\
\text { Companies and Article } 4 \text {. of the } \\
\text { Decree that promotes the organization } \\
\text { of Integrating Companies published in } \\
\text { the Official Gazette of the Federation } \\
\text { on May } 7,1993 \text { and its modifications } \\
\text { on May } 30,1995 \text {. } \\
\text { Economic-financial feasibility project } \\
\text { that supports integration. } \\
\text { Obtain the registration card in the } \\
\text { National Registry of Integrating } \\
\text { Companies. }\end{array}$ \\
\hline Execution & $\begin{array}{l}\text { The implementation of what is } \\
\text { embodied in the project. }\end{array}$ \\
\hline
\end{tabular}

Table 2 Stages to form the integrating companies Source: Prepared by the author based on the Ministry of Economy (s.f.)

\section{Limitations that exist for the Integrating Company}

It is important to mention the limitations that this type of model presents in order to take them into account, to minimize the risk of its operation:

1. Individuals or legal entities that are not formally constituted may not be members of an integrating company.

2. You cannot carry out any part of the production process that involves the activity of your associates.

3. Unfair practices are not allowed or have monopolistic activities. 
4. The assets acquired for the productive process of the members cannot be part of the integrator.

5. The integrating company acts exclusively on behalf of its partners.

A common denominator in the concepts of both an integrating company and an export consortium is that of a strategic alliance, given that both schemes are configured based on these business interests. Renart (1999, p.3) states that "it is a voluntary, medium or long-term collaboration agreement between two or more independent companies, in order to carry out certain actions in a coordinated manner to achieve certain results".

\section{Export Consortium}

The United Nations Industrial Development Organization (UNIDO, 2004), defines the export consortium as a voluntary alliance of companies with the objective of promoting the goods and services of its members abroad and facilitating the export of its products through joint actions. Renart (1999) conceptualizes this figure as a voluntary cooperation agreement between two or more companies with the objective of jointly developing their foreign markets. An export consortium is a particular case within the types of strategic alliances between companies.

Barrera (2015) indicates that the consortium is the meeting of two or more natural or legal persons, who carry out the same or similar economic activities, with the purpose of regulating their market concurrence with respect to the goods they produce or produce, or services they provide Likewise, Espejo, Fuentes and Núñez (2015) affirm that the joint cooperation that SMEs carry out allows them to be competitive because they take advantage of commercial opportunities that are global.

\section{International historical background of the Export Consortium}

Gordiola (1975) performs an evolutionary analysis of export consortia based on the neoclassical approach of international trade theories, where the international division of labor begins, which allows each country to specialize and export those goods that can produce cheaper. The first antecedent with the characteristics of an export consortium arises in the British economy between 1850 and 1875 .
On the other hand, Levin (1960) analyzed and concluded that for more than four centuries the export industry did not provide an important boost to economic development. of the countries. In addition, he stressed the importance of export fluctuations in them.

Finally, Madhok (1996) affirms that in the business context the strategic decisions of a company are the basis of its internationalization.

\section{Historical background of the Export Consortium in Mexico}

During the mid-1980s, Mexico was one of the most closed economies in the world, imposing high tariffs on import products, as part of the import substitution strategy aimed at generating internal economic development (Malaga and Williams, 2010).

As the first antecedent of the export consortia in the country, there is the entry of Mexico to the General Agreement on Tariffs and Trade (GATT) in 1986, which opened the international markets, giving way, among others, to the signature and subsequent entry into force of NAFTA. Subsequently, Mexico decided to diversify its export markets through other bilateral trade agreements, such as the Economic Complementation Agreement with Chile, which opened the door to Latin American trade. Then, being within all these trade agreements, small and medium-sized companies that did not have sufficient capacity to export were forced to seek new strategic business alliances and, having as an international reference the export consortia, said figure began to be implemented in Mexico.

\section{Types of Export Consortiums}

Export consortia have differences in the services they provide, that is, the activities that each company develops gives rise to the specialization of each type of consortium. A different type of consortium.

According to the United Nations Industrial Development Organization (2004), two main types of consortium can be distinguished: 
a. Promotion consortiums: an alliance created to explore export markets determined by sharing promotion and logistics costs, the latter constitute an entity that channels member exports. In this way, promotional consortiums are limited to promoting the products of their members and helping them to have access to foreign markets.

b. Sales consortia: they carry out commercial promotion activities and organize the sale of the products of the participating companies. To ensure a certain image, these types of consortiums usually control the quality of the products marketed. While the number of participating companies is generally limited in a sales consortium, promotion consortiums usually have a significant number of members.

These, in turn, are divided into two subtypes: A. Trade consortia: those that acquire the products of the participating companies to resell them. B. Consortia that act as export agents: the participating companies that send their own receipts and try to obtain payment from their customers. Also, within this categorization, several export consortium variables can be determined, which are found in Table 3 .

\begin{tabular}{|l|l|}
\hline \multicolumn{2}{|c|}{ Variables } \\
$\begin{array}{l}\text { Consortia of a } \\
\text { multisectoral and }\end{array}$ & $\begin{array}{l}\text { For those in a single sector, they allow } \\
\text { activities to focus on the most efficient } \\
\text { product of companies. The partners } \\
\text { know each other better, allowing } \\
\text { effective cooperation. } \\
\text { For multisectoral consortia, they } \\
\text { include participating companies with } \\
\text { different money orders and products, } \\
\text { which avoids competition between } \\
\text { members. }\end{array}$ \\
\hline $\begin{array}{l}\text { Consortia that } \\
\text { group competitors } \\
\text { and non- } \\
\text { competitors }\end{array}$ & $\begin{array}{l}\text { When created from those who are } \\
\text { direct competitors, activities can be } \\
\text { directed to the specific product, which } \\
\text { can lead to economies of scale. }\end{array}$ \\
\hline $\begin{array}{l}\text { Regional consortia } \\
\text { and } \\
\text { comprising those } \\
\text { members from } \\
\text { various regions }\end{array}$ & $\begin{array}{l}\text { They usually have a specific local } \\
\text { objective, while those from more } \\
\text { regions contact companies at different } \\
\text { geographical points. }\end{array}$ \\
\hline $\begin{array}{l}\text { Consortia oriented } \\
\text { to a specific region } \\
\text { and those that carry } \\
\text { out activities } \\
\text { worldwide }\end{array}$ & $\begin{array}{l}\text { If the markets to which a specific } \\
\text { consortium is oriented are within the } \\
\text { same area, transportation, operating } \\
\text { and information and advertising } \\
\text { expenses can be reduced. However, } \\
\text { when the activities of this consortium } \\
\text { grow worldwide, the diversification of } \\
\text { export markets also increases. }\end{array}$ \\
\hline
\end{tabular}

Table 3 Variables of export consortia

Source: Own elaboration with data from UNIDO (2004)
Castro and Moneu (1993) offer another classification of export consortia: a. Export consortia at source and destination; $b$. Commercial promotion and sale consortiums; $\mathrm{c}$. Monosectorial or multisectoral consortia; and $\mathrm{d}$. Consortia depending on the geographical scope of their partner companies or their commercial activities.

\section{Characteristics of the participating companies}

UNIDO (2004) clarifies that participants in the export consortium model must meet the following characteristics:

Have the objective of developing foreign markets and their investment mentality. Willingness to cooperate with other companies to achieve the objectives.

Trust among the members to achieve the effective functioning of the consortium. Pre-existing relationships between members and transparent consortium operations to facilitate trust.

Products and services that adapt to the markets in which the consortium will have a presence.

- Commitment to manage financial resources.

One of the most important services provided by export consortia is the organization of the participation of partner companies in exhibitions and industrial fairs abroad (UNIDO, 2008). However, the size of a consortium influences the offer of services that it can offer. There is no specific number of participating companies to establish an export consortium, but it does depend largely on the objective, obviously the more companies the consortium has, the more benefits can be obtained.

\section{Benefits or advantages granted by the Export Consortiums}

Every entrepreneur who wants to increase or start exports seeks to obtain benefits and advantages that allow his company to be more competitive both in the national and international markets. 
Renart (1999), identifies the following benefits and advantages offered by export consortia, classifying them into two types: a. economic benefits: increase in exports, international sales with a wide profit margin, diversification of commercial risk, government support from governments through the export consortium program, savings in administrative and logistic expenses (go to international fairs as a team, export several partner-companies in the same container Creation of a collection of different ranges of products to be exported that is more attractive and complete that increases the bargaining power with end customers abroad $\mathrm{B}$. Learning benefits: in export operations, operational learning on issues of negotiations with banks, application of collective agreements, location of a good supplier of a raw material, implementation of standards Learning in the participation of strategic alliances, selection of potential partners, terms of agreements.

\section{Main disadvantages when participating in an Export Consortium}

This section will briefly explain the challenges that a consortium may face during its existence, according to three sources. UNIDO (2004) classifies the challenges into two types:

c) Internal: they refer to the problems that could arise due to the organization or management of the consortium and possible conflicts between the members.

d) External: they concern the difficulties of the environment in which the consortium operates.

The following Table shows the main challenges according to their classification

\begin{tabular}{|c|c|}
\hline Interns & External \\
\hline $\begin{array}{l}\text { Competition between } \\
\text { members and lack of trust. }\end{array}$ & $\begin{array}{l}\text { The inexperience of } \\
\text { financial and support } \\
\text { institutions with respect to } \\
\text { consortia that complicates } \\
\text { operations and hinders the } \\
\text { obtaining of assistance } \\
\text { from public bodies. }\end{array}$ \\
\hline $\begin{array}{l}\text { Members may be reluctant to } \\
\text { participate without reservation } \\
\text { in a consortium. }\end{array}$ & $\begin{array}{l}\text { Unfavorable } \\
\text { macroeconomic and } \\
\text { political environment, } \\
\text { export orders may not } \\
\text { increase even though the } \\
\text { promotion activities of the } \\
\text { consortium are adequate. }\end{array}$ \\
\hline $\begin{array}{l}\text { Conflicts regarding financial } \\
\text { contributions to be made. } \\
\text { Emergence of tensions if } \\
\text { members obtain different } \\
\text { export results. }\end{array}$ & $\begin{array}{l}\text { Customers can accuse } \\
\text { participating companies of } \\
\text { complicity and unilateral } \\
\text { pricing. }\end{array}$ \\
\hline $\begin{array}{l}\text { Customers can accuse } \\
\text { participating companies of } \\
\text { collusion and pricing. It is } \\
\text { more likely that the price } \\
\text { increases of the products of the } \\
\text { participating companies are } \\
\text { due to improvements in quality } \\
\text { and design and not to } \\
\text { collusion. }\end{array}$ & \\
\hline $\begin{array}{l}\text { Differences in the volume of } \\
\text { intangible benefits derived } \\
\text { from the consortium, such as } \\
\text { the learning of certain } \\
\text { activities, which may cause the } \\
\text { consortium to leave to } \\
\text { continue with individual } \\
\text { exports. }\end{array}$ & \\
\hline
\end{tabular}

Table 4 Internal and external drawbacks of export consortia

Source: Own elaboration with data from UNIDO (2004)

\section{Financial support to the Export Consortiums}

The Mexican government has a support program for the formation of export consortiums, in this section there are two programs that small and medium entrepreneurs can use if they want financing. The first corresponds to the advice for the formation of export consortiums (ReDex). This program has been in effect since June 18, 2018. It offers advisory services to start, guide and organize a formal business association preferably with the same channel of distribution abroad to promote their products and services jointly. The amount of support is reimbursed in up to two installments, it is not subject to VAT. The amount must be requested by the company representing at least five companies or individuals with business activity. 
You can request it ${ }^{1}$ Mexican SMEs and individuals with business activity with export potential or already exporters. For the prospecting and preparation stage, the report on the realization of the sensitization seminar that includes minutes is presented; attendance list and photographic memory; market study; export diagnostic application results (Export Check Up); Report on training and technical assistance activities that include minutes, attendance list and photographic memory; RedEx international promotion program that includes an international marketing plan with promotional actions to be carried out.

Implementation stage: Charter of the RedEx; Rules of Procedure; Organic structure of the RedEx; Fund of contributions.

The second is that of the Institutional Fund for Regional Development for Scientific, Technological and Innovation Development (FORDECYT), which is an instrument whose purpose is to promote scientific, technological and innovation actions, as well as the training of specialized human resources that contribute to regional development, to the collaboration and integration of the regions of the country, and to the strengthening of local, state and regional systems of science, technology and innovation.

Third, there is the Regional Development Program for Scientific, Technological and Innovation Capabilities (National Council of Science and Technology CONACYT, 2014). The benefits offered by the National Fund are: It focuses attention to regional demands, with projects or interventions of science, technology and innovation of high relevance and social sense. It operates through a process of consultation, consensus and consultation with key people and opinion sectors of regional development. It generates participatory environments consistent with the challenge of regional integration and definition of development problems that can be addressed with science, technology and innovation. It distributes the Stock Exchange in an equitable manner according to the 6 CONACYT regions and a global Stock Exchange to projects with relevance and high technical quality of any of the 6 regions.
They can participate: Institutions, public universities and / or individuals. Public and private centers, laboratories and companies dedicated to scientific research, technological development and innovation, which are registered in the National Registry of Institutions and Scientific and Technological Companies (RENIECyT).

\section{Exportable Offer}

The concept of exportable supply is essential for consortia and integrating companies to generate opportunities that will be directed abroad. Huaytalla (2016, p.30) defines this term based on its purpose, which aims to "develop actions to reach a strategically diversified offer, with significant added value, quality and volumes that allow a competitive presence in the markets international ". This is based on 3 aspects: 1 . Product availability, 2. Economic and financial capacity of the company and 3. Management capacity. (Ministry of Agriculture and Irrigation of Peru, 2018).

\section{Fair trade and compensatory trade}

Likewise, the Fair Trade practice, as an alternative activity in international trade, also underlies the operations of the integrating companies and export consortia. One of the clearest definitions of this term is established by the World Fair Trade Organization (2018), who defines it as a global social movement that promotes other types of trade, based on dialogue, transparency, respect and equity. This practice contributes to the assurance of the rights of micro and small entrepreneurs, in addition to small producers and workers who are disadvantaged before large companies.

"Fair Trade organizations are committed to supporting producers, raising awareness and developing campaigns to achieve changes in the rules and practices of conventional international trade" (World Fair Trade Organization, 2018). For this reason, both the concept of fair trade and exportable supply have been considered as part of the conceptual framework in this investigation.

\footnotetext{
${ }^{1}$ Se describen todos los requisitos puntuales, tal y como se enlistan originalmente en el Decreto correspondiente. 
In parallel, the compensatory trade has its most graphic description in the sogo soshas that began in Japan, which began simply and then transcended in large firms that use their collaboration networks to sell the products through compensatory businesses. (Hill, 2015).

\section{Methodology}

The methodology used in this research refers to qualitative research, with an exploratory approach and secondary sources. (Hernández et al., 2014). The design applied to this research is a grounded theory, given that the categories of the two models of international trade association have been analyzed: consortium and integrating export company, comparing benefits, challenges and elements of each one and that are applied to a Mexican context specifically, that is to say for SMEs.

\section{Results}

In Mexico, according to the data available to the Ministry of Economy (2019), there are a total of 1,197 integrating companies that are distributed as follows: agricultural sector 435, manufacturing 184 , mining 3 , construction 99 , commerce 99 communications and transportation 45 and services 276.

For export consortia, the numbers indicate that in Mexico, 31 consortiums have been created in the States of Jalisco, Federal District and Zacatecas. The following Table concentrates the data in specific.

\begin{tabular}{|l|l|}
\hline \multicolumn{1}{|c|}{ State - number } & \multicolumn{1}{c|}{ Sectors } \\
\hline Jalisco (20) & $\begin{array}{l}\text { Auto parts, fashion, footwear, } \\
\text { tequila, graphic arts, veterinary } \\
\text { medicine, 3D animation, ICT, } \\
\text { digital arts, painting and } \\
\text { sculpture, performing arts, art } \\
\text { and sculpture, crafts and } \\
\text { jewelry. }\end{array}$ \\
\hline Zacatecas (7) & $\begin{array}{l}\text { Greenhouse vegetables } \\
\text { Food and mechanical metal } \\
\text { Mexico City (4) }\end{array}$ \\
\hline
\end{tabular}

Table 5 Export consortia in Mexico Source: own elaboration with data from Cerdan and UNIDO (2012)

Also, in the following comparative table presented below, the characteristics of both the exporting integrating company and the export consortium are shown.

\begin{tabular}{|c|c|c|}
\hline $\begin{array}{l}\text { Model } \\
\text { Concept }\end{array}$ & $\begin{array}{l}\text { Integrative } \\
\text { Exporting } \\
\text { Company }\end{array}$ & Export Consortium \\
\hline Objective & $\begin{array}{l}\text { Raise the } \\
\text { bargaining power of } \\
\text { MSMEs and } \\
\text { consolidate their } \\
\text { presence in the } \\
\text { internal and } \\
\text { external market. }\end{array}$ & $\begin{array}{l}\text { Promote the goods and } \\
\text { services of its members } \\
\text { abroad to facilitate the } \\
\text { export of its products } \\
\text { through joint actions. }\end{array}$ \\
\hline $\begin{array}{l}\text { Function that } \\
\text { develops }\end{array}$ & $\begin{array}{l}\text { Acquisition, } \\
\text { adaptation, } \\
\text { assimilation and } \\
\text { technological } \\
\text { innovation, national } \\
\text { and international } \\
\text { market search, } \\
\text { access } \\
\text { specialized design } \\
\text { services, achieve } \\
\text { greater market } \\
\text { penetration. }\end{array}$ & $\begin{array}{l}\text { Planning, coordination } \\
\text { and implementation of } \\
\text { internationalization } \\
\text { strategies, financing } \\
\text { management for partners. } \\
\text { Development of } \\
\text { improvements in product } \\
\text { quality and services. }\end{array}$ \\
\hline Characteristics & $\begin{array}{l}\text { Operational } \\
\text { flexibility, better } \\
\text { negotiating position } \\
\text { in the national and } \\
\text { international } \\
\text { market. } \\
\text { Acquisition, } \\
\text { adaptation, } \\
\text { assimilation and } \\
\text { innovation in } \\
\text { technology. } \\
\text { Specialized } \\
\text { financial advice. } \\
\text { It includes MSMEs. }\end{array}$ & $\begin{array}{l}\text { Reach in foreign markets } \\
\text { and attract investment. } \\
\text { Partner companies have } \\
\text { access to capital from } \\
\text { other companies that help } \\
\text { them. } \\
\text { The consortium directors } \\
\text { are responsible for } \\
\text { developing } \\
\text { internationalization plans } \\
\text { for members. }\end{array}$ \\
\hline Benefits & $\begin{array}{l}\text { Raise } \\
\text { competitiveness } \\
\text { Create economies } \\
\text { of scale for your } \\
\text { associates. } \\
\text { It favors the } \\
\text { concurrence to new } \\
\text { national or } \\
\text { international } \\
\text { markets. } \\
\text { Flexibility to adapt } \\
\text { to any economic } \\
\text { activity. }\end{array}$ & $\begin{array}{l}\text { Increase in exports. } \\
\text { International sales with } \\
\text { good profit margin. } \\
\text { Diversification } \\
\text { commercial risk. } \\
\text { Subsidies from } \\
\text { governments through the } \\
\text { export consortium } \\
\text { program. } \\
\text { Distribution of expenses } \\
\text { not covered by possible } \\
\text { subsidies among the } \\
\text { partner companies of the } \\
\text { consortium. }\end{array}$ \\
\hline Partners & $\begin{array}{l}\text { It starts with a } \\
\text { minimum of } 4 \\
\text { partners, however, } \\
\text { it is recommended } \\
\text { that it does not } \\
\text { exceed } 50 \text { in its first } \\
\text { stage of operation. }\end{array}$ & $\begin{array}{l}\text { Minimum number of } 3 \\
\text { partners. } \\
\text { There is no maximum } \\
\text { number of partner } \\
\text { companies. }\end{array}$ \\
\hline $\begin{array}{l}\text { Economic } \\
\text { capacity of the } \\
\text { partners }\end{array}$ & Medium & Medium \\
\hline $\begin{array}{l}\text { Expectations to } \\
\text { improve the } \\
\text { competitiveness } \\
\text { of partner } \\
\text { companies }\end{array}$ & High & All \\
\hline $\begin{array}{l}\text { Financial } \\
\text { support }\end{array}$ & Yes & Yes \\
\hline $\begin{array}{l}\text { Propitiate } \\
\text { economies of } \\
\text { scale }\end{array}$ & Yes & Yes \\
\hline $\begin{array}{l}\text { Productive } \\
\text { activities }\end{array}$ & All & All \\
\hline
\end{tabular}

Table 7 Comparison of figures of integrating company and export consortiums

Source: Prepared by the author with data from the Ministry of Economy, National Entrepreneur Institute, ProMéxico, United Nations Industrial Development Organization 
Through the analysis and diagnosis of the information collected, the concept of the integrating exporting company and the export consortium was announced, both figures were created in order to increase the competitiveness of companies that have an export potential, but present some differences:

The integrating exporting company is the one born with the integration of the mypes.

The export consortium is made up of small and medium-sized companies, as well as other larger or commercial operations.

The integrating company has a series of fiscal support and specialized advice from its training stages and at any time it requires it, this will depend on the doubts, problems or situations that arise.

The integrating company gives much greater ease of access to those micro businesses that want to be part of it, since they may or may not register with the Ministry of Economy, a disadvantage of this would be that, if the registration was not made, no They will be able to access programs for export promotion. In the case of consortiums destined for sale, the main challenge is how to organize export operations between the various members and the consortium.

Finally, the results of this investigation showed that both the figure of the exporting integrating company and the export consortium have many similar characteristics, however, it depends on the type of sector in which the partners are going to associate. If a company is micro scale, it is best to associate under the scheme of integrating company. In this context, it will be the decision of the entrepreneur under which scheme you want to integrate following the process of formation and / or constitution of this.

\section{Conclusions}

Based on these results, the research suggests that the figure of an integrating exporting company is ideal for small entrepreneurs to enjoy the series of benefits and supports it provides.
This will depend on the size of the company you have and the international expansion strategies that are related to the strategic planning of the companies.

One of the most frequent problems among MSMEs is that they do not have the necessary resources to carry out foreign trade operations, this includes export and import, international marketing, technology, design, etc. Given the international background presented, it is known that the creation of strategic alliances such as those presented in the document is of paramount importance for the economic growth of a country.

It is concluded that, broadly speaking, there are no substantial differences between the figure of the exporting integrating company and the export consortium since both have practically the same characteristics and offer the same benefits, however, among the small differences, it was found that Integrative companies give more support to microenterprises, while the export consortium focuses on small and medium-sized enterprises. Therefore, the interested entrepreneur should carefully review both figures to determine which one is most beneficial depending on the characteristics of your company.

In addition, the continuous creation and implementation of export networks that allow MSMEs the growth necessary for their internationalization regardless of their sector is important. Another key point is that the Mexican government has implemented several export support programs, which represents an advantage for interested parties to access financial resources.

\section{Acknowledgments}

The authors of this paper express their gratitude to the University of Guanajuato for the support and financing provided for its publication.

\section{References}

Barrera, J. (s.f.). Consorcio en México. Recuperado el 22 de noviembre de 2018, de https://mexico.leyderecho.org/consorcio/\#Cons orcio_en_la_Legislacion_Mexicana.

Castro, M. y Moneu, I. (1993). Los consorcios de exportación. (718), 63-78. 
Consejo Nacional de Ciencia y Tecnología [CONACYT] (2014). Fondo Institucional de Fomento Regional para el Desarrollo Científico, Tecnológico y de Innovación (FORDECYT). Recuperado el 22 de noviembre de 2018, de https://www.conacyt.gob.mx/index.php/fondoinstitucional-de-fomento-regional-para-eldesarrollo-cientifico-tecnologico-y-deinnovacion-fordecyt.

Diario Oficial de la Federación [DOF]. (1993). Decreto que promueve la organización de Empresas Integradoras. Recuperado de http://www.dof.gob.mx/nota_detalle.php?codig $\mathrm{o}=4735831 \&$ fecha $=07 / 05 / 19$.

Espejo, A., Fuentes, F. y Núñez, J. (2015). Los consorcios de exportación: revisión conceptual y factores determinantes de éxito. Revista de Estudios Empresariales. 2(2015). Págs. 118 144

Gordiola, A. (1975). Consorcios de Exportación. (Tesis doctoral) Universidad de Buenos AiresFacultad de Ciencias Económicas.

Hernández, R., Fernández, C. y Baptista, P. (2014). Metodología de la investigación ( $6^{\mathrm{a}} \mathrm{Ed}$.). México, D.F., México: McGraw Hill Interamericana.

Huaytalla, C. (2016). Generación de oferta exportable mediante la sustitución de cultivos de papa hacia la producción de quinua en la cooperativa virgen del Carmen-Ayacucho para su comercialización en el mercado de TorontoCanadá. (Tesis de licenciatura). Facultad de Ciencias Administrativas y Recursos Humanos.

Hill, C. (2015). International Business. Competing on the Global Marketplace. McGraw Education: USA.

Instituto Nacional del Emprendedor. (s.f.). Empresas Integradoras. Recuperado el 19 de noviembre de 2018, de https://www.inadem.gob.mx/empresasintegradoras/.

Málaga, J. y Williams, G. (2010). La competitividad de México en la exportación de productos agrícolas. vol. 27, 295-309.
Madhok, A. (1996). The Organization of Economic Activity: Transaction Costs, Firm Capabilities, and the Nature of Governance. Recuperado el 24 de noviembre, de https://www.researchgate.net/publication/23833 7511_The_Organization_of_Economic_Activit y_Transaction_Costs_Firm_Capabilities_and_t he_Nature_of_Governance.

Marín, C. (2017). Papel que Desempeñan las Empresas Integradoras. (Licenciatura). Universidad Autónoma Agraria Antonio Narro.

Ministerio de Agricultura y Riego. (s.f.). Definición de Oferta Exportable. Recuperado el 18 de noviembre de 2018, de http://minagri.gob.pe/portal/objetivos/181exportaciones/que-podemos-exportar/532definicion-de-oferta-exportable.

Organización de las Naciones Unidas para el Desarrollo Industrial [ONUDI]. (2004). Guía de los consorcios de exportación. Recuperado el 21 de noviembre de 2018, de https://www.unido.org/sites/default/files/200809/Guia_de_los_consorcios_de_exportacionSpanish_guide_0.pdf.

Organización Mundial del Comercio [OMC]. (s.f.). Comercio justo. Recuperado el 12 de noviembre de 2018, de http://www.wftola.org/comercio-justo/que-es/.

PROMEXICO. (s.f.). Asesoría para la formación de consorcios de exportación. Recuperado el 21 de noviembre de 2018, de $\mathrm{http} / / / \mathrm{www}$.promexico.mx/es/mx/asesoriaformacion-consorcios-exportacion-redex.

Renart, Ll. (1999). Consorcios de Exportación y otros tipos de Alianzas Estratégicas entre Empresas. (2627), 1-18.

Reyes, O. (2011). Empresas integradoras para el beneficio del agro. (47), 111-128.

Secretaría de Economía [SE]. (s.f.). Guía para la formación de una empresa integradora. Recuperado el 18 de noviembre de 2018, de http://www.contactopyme.gob.mx/integradoras/ h_guias.html.

Secretaría de Economía. (2019). Programa de Empresas Integradoras. Recuperado el día 9 de septiembre de 2019, de http://www.contactopyme.gob.mx/integradoras/ directorio.asc

ARREDONDO-HIDALGO, María Guadalupe, CONRAUDKOELLNER, Eva, ALCOCER-LUQUE María Clementina and MORENO-ÁVILA, Fátima de la Purísima. Comparative Analysis between the Integrating Company model and the Export Consortium in Mexico. Journal-Public Economy. 2019 